JOURNAL OF AGRICULTURE AND APPLIED BIOLOGY

2020, Vol. 1, No. 2, $64-73$

http://dx.doi.org/10.11594/jaab.01.02.04

Research Article

\title{
Use of GIS in soil fertility mapping of Rapti Municipality, Chitwan, Nepal
}

\author{
Biplov Oli ${ }^{*}$, Sushil Lamichhane ${ }^{2}$, Khem Oli ${ }^{3}$ \\ 1Purbanchal University, Gothgaun, Morang, Nepal \\ ${ }^{2}$ Nepal Agriculture Research Council, Khumaltar, Kathmandu, Nepal \\ ${ }^{3}$ Center for Environmental and Agricultural Policy Research, Extension \\ and Development (CEAPRED), Lalitpur, Nepal
}

Article history:

Submitted 09 October 2020

Accepted 14 November 2020

Published 25 December 2020

Keywords:

Fertilizer

GPS

Mapping

SSNM

*Corresponding author:

E-mail:

sharmabipoli@gmail.com

\begin{abstract}
Mapping the spatial distribution of soil fertility in a particular area gives an idea about the nutrient content in the soil which plays an important role in fertilizer recommendation, sustainable soil management, integrated plant nutrient management, land use planning, and site-specific nutrient management (SSNM). A study was carried out to assess the soil fertility status of the Rapti Municipality, Chitwan, Nepal. A total of 120 soil samples was collected based on land use, slope, and aspects with the use of Google Earth Pro (GEP) and ArcGIS. Based on the soil test report spatial variation of soil texture, soil $\mathrm{pH}$, total nitrogen, available phosphorous, and potassium of the study area was prepared. The majority of the study area (57.11\%) has sandy clay soils. The soil $\mathrm{pH}$ was very strongly acidic to slightly alkaline with $\mathrm{pH}$ values ranging from 4.8 to 8.0 . Soil organic matter (1.94-3.75\%), total nitrogen (0.097-0.187\%), available phosphorous (51.03-270.10 kg $\left.\mathrm{ha}^{-1}\right)$, and available potassium (169.87-358.68 $\mathrm{kg} \mathrm{ha}^{-1}$ ) in the soil are within the range of medium to high in the study area. To maintain this nutrient status, the use of organic manure, reduced use of chemical fertilizers, and different soil management practices should be adopted in this area.
\end{abstract}

\section{Introduction}

Soil fertility is one of the most important factors for soil productivity. However, soil erosion, landslides, flood, and other different soil degradation factors cause a serious problem in rapid nutrient depletion and pose a great challenge in soil fertility management. Therefore, soil fertility evaluation and its spatial distribution play an important decision-making role in planning a particular land-use system (Havlin et al., 2010). Nepal is an agricultural country with about $66 \%$ of the population engaged in agriculture (MoAD, 2016). About 2 billion people in the world suffer from moderate to severe food insecurity (FAO et al., 2019). In the context of Nepal, about $52 \%$ of the households are suffering from food insecurity (Nepal Demographic and Health Survey 2016). IFPRI (2017) reported that about two million people are undernourished in Nepal. To achieve self-reliance in crop production, soil fertility plays a crucial role. 
Soil testing and its analysis of physical, chemical and biological properties is a prerequisite for sustainable soil management (Panda, 2010). Soil tests provide the data on nutrient content in a particular soil which can be the basis for the recommendation of fertilizers for increased crop production. Mapping the status and the spatial distribution of soil fertility plays an important role in the sustainable land use planning process (Khadka et al., 2018). The use of new technologies like GIS and GPS makes it easy in describing the spatial variability of soil fertility for a larger area. For collection, storage, retrieving, transformation and display of data, geographic information systems (GIS) is a powerful software tool (Burrough et al., 2015). Several studies have been conducted to characterize the spatial variability of different soil properties using GIS software tools (Hung et al., 2007; Liu et al., 2013; Khadka, 2018; Rawal, 2018). Soil fertility mapping with the use of GIS and remote sensing (RS) data helps to evaluate the nutrients status in the soil concerning the land use/cover and different physiographic units (Binita, Dasog and Patil, 2010). Soil fertility mapping and its spatial distribution is also an important requirement for site-specific nutrient management and farming practices (Patil et al., 2016). For the proper utilization of the agricultural land, crop production opportunities and constraints, land suitability and proper land use planning soil fertility mapping are essential (Rawal et al., 2018). In this study, we attempt to prepare the spatial distribution of soil fertility maps with the use of laboratory analysis soil test data.

\section{Materials and Methods Study area}

The study was conducted at the Rapti Municipality of Eastern Chitwan covering 212.46 $\mathrm{km}^{2}$ areas. The Rapti municipality is situated at the latitude of $27.64152{ }^{\circ} \mathrm{N}$ and longitude $84.61825^{\circ} \mathrm{E}$. The total area of the Chure range in Chitwan district is $1888.58 \mathrm{~km}^{2}$, i.e. $85.14 \%$ of the total area. Elevation within the research boundary varies from 209 to 1923 meters which increases from South to North. Rapti Municipality of the Eastern Chitwan valley is located in the Central Region of Nepal where an ideal and conducive environment can be found for agriculture and livestock production. The research area covers the protected community forest, barren and agricultural land and larger settlement areas. The climate of the Rapti Municipality area is characterized by a warm and sub-tropical condition. The temperature rises to $40{ }^{\circ} \mathrm{C}$ from March to June. The average temperature of $25^{\circ} \mathrm{C}$ is experienced from October to February. The annual average precipitation of the study area is $1955 \mathrm{~mm}$ (Department of Hydrology and Meteorology). Most of the population of the study area is engaged in agriculture. As soil fertility status directly influences the agricultural phenomenon, its estimation, assessment and mapping are important for the sustainability of the Agroecosystem. The major cropping patterns followed in the Rapti Municipality are rice-mustard-rice, rice-lentil-rice, rice-wheat-rice, rice-maize-rice, maize-fallowmaize, rice-fallow-maize and maize-fallowbuckwheat.

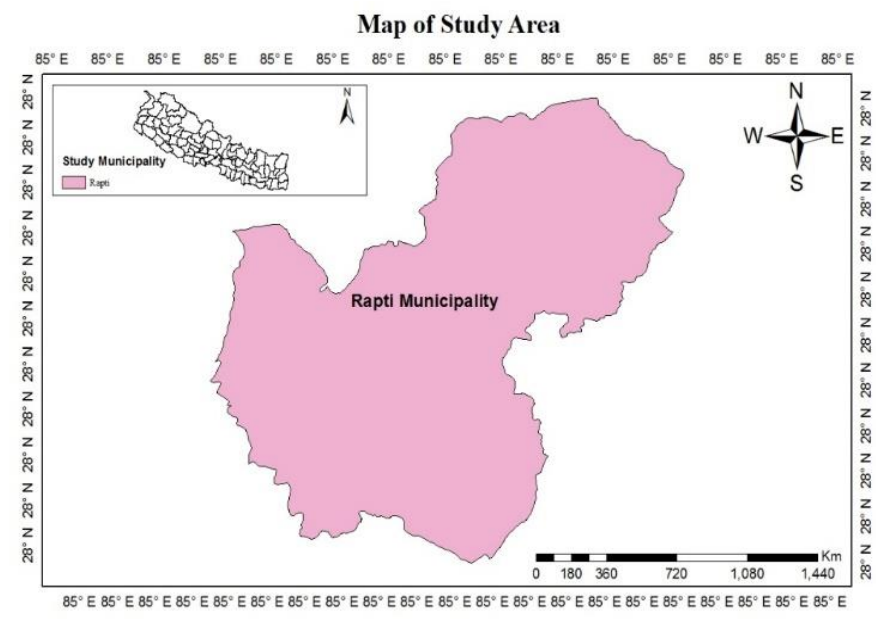

Figure 1. Location map of Rapti Municipality, Chitwan, Nepal 


\section{Soil survey methods}

A total of 120 soil samples from the top 0 $20 \mathrm{~cm}$ were taken from 13 different wards of the Rapti Municipality. Soil samples were taken systematically using the Google Earth Pro (GEP) and ArcGIS software base on the land cover/land use, slope and aspects. To locate the soil sampling pits, a GPS device was used. Primary nutrients present in soil (NPK), soil $\mathrm{pH}$ and soil texture were analyzed in the soil testing laboratory. The rating classes of soil parameters and $\mathrm{pH}$ is given in Table 1 and 2 respectively. The location of soil sampling points in the Rapti Municipality is shown in Figure 2. Digital elevation model (DEM) from the USGS Earth Explorer published on 23rd September 2014 was downloaded to determine the elevation, slope and aspect of any point inside the study area by using Arc GIS software. The elevation ranges from 209 to 1923 meters as shown in Figure 3.

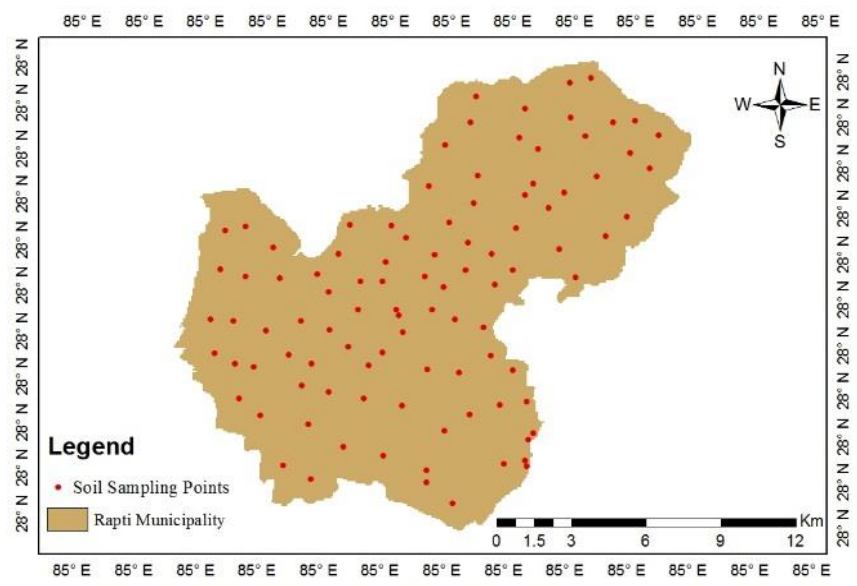

Figure 2. Soil sampling points inside the Rapti Municipality, Chitwan, Nepal

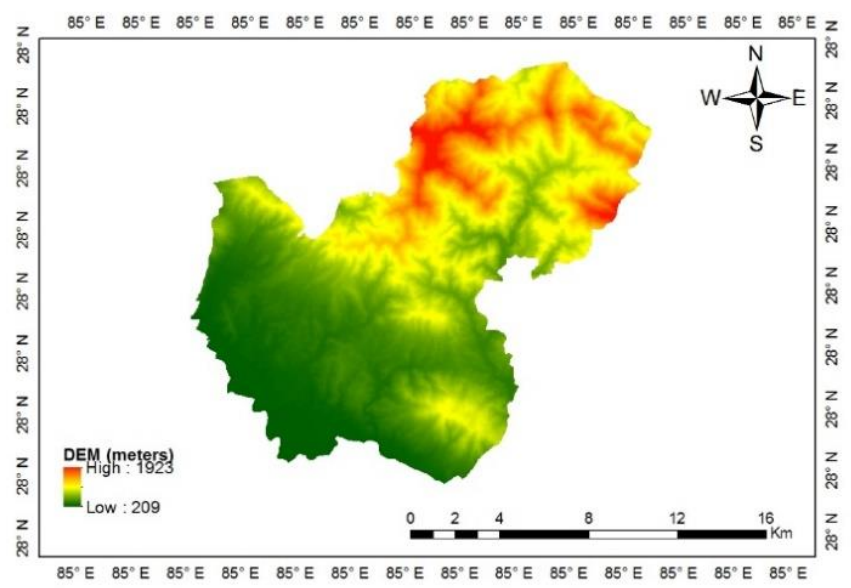

Figure 3. Digital elevation model of Rapti Municipality, Chitwan, Nepal

Table 1. Different rating classes of soil test data adopted by soil testing laboratory, Nepal

\begin{tabular}{cllccccc}
\hline SN & Soil parameters & Unit & Very low & Low & Medium & High & Very high \\
\hline 1 & Organic matter & $\%$ & $<0.75$ & $0.75-1.5$ & $1.5-3.0$ & $3.0-5.0$ & $>5$ \\
\hline 2 & Total $\mathrm{N}$ & $\%$ & $<0.03$ & $0.03-0.07$ & $0.07-0.15$ & $0.15-0.25$ & $>0.25$ \\
\hline 3 & Available $\mathrm{P}_{2} \mathrm{O}_{5}$ & kg ha $^{-1}$ & $<11$ & $11-28$ & $28-56$ & $56-112$ & $>112$ \\
\hline 4 & Available $\mathrm{K}_{2} \mathrm{O}$ & kg ha $^{-1}$ & $<55$ & $55-110$ & $110-280$ & $280-500$ & $>500$ \\
\hline
\end{tabular}


Table 2. Rating of soil according to $\mathrm{pH}$ adopted by soil testing laboratory, Nepal

\begin{tabular}{ll}
\hline Soil reaction $(\mathrm{pH})$ & $\mathrm{pH}$ range \\
\hline Extremely acidic & $<4.5$ \\
Very strongly acidic & $4.5-5.0$ \\
Strongly acidic & $5.0-5.5$ \\
Moderately acidic & $5.5-6.0$ \\
Slightly acidic & $6.0-6.5$ \\
Nearly neutral & $6.5-7.5$ \\
Slightly alkaline & $7.5-8.0$ \\
Moderately alkaline & $8.0-8.5$ \\
Strongly alkaline & $8.5-9.5$ \\
Very strongly alkaline & $9.5-10$ \\
Extremely alkaline & $>10.0$ \\
\hline
\end{tabular}

\section{Data sources}

Data sources used in this research included the Digital Elevation Model (DEM) and soil test data. The DEM was used to generate the slope, aspect and hill shade required for sampling soils. By using the DEM, the elevation of the study area was calculated. Analysis of the soil samples was carried out in the laboratory to determine the soil $\mathrm{pH}$, texture, total nitrogen, available phosphorous and available potassium to prepare the soil fertility maps.

\section{Statistical analysis and soil fertility mapping}

Soil parameter data with the sample points coordinates i.e. latitude and longitude was entered in a spreadsheet. This data was added to ArcGIS version 10.3 software for necessary processing. Ordinary kriging interpolation tool was used to prepare the soil fertility maps and Thiessen polygon was used to prepare the soil $\mathrm{pH}$ and textural class maps of the study area. Ordinary krigging tool has minimum estimation variance (Kumke et al., 2005). Interpolation is one of the important geostatistical tools which helps to estimate the values of unsampled points so as to prepare continuouis dataset to study the spatial distribution (Gunarathna et al., 2016). Thiessen polygon delineate the polygon on the basis of space occupied by each sample points such that any location in the polygon is closer to the original sample point than to any other sampling points (Andujar et al., 2013; Bermingham et al., 2014). Thiessen polygon is an important tool in mapping categorical point information.

\section{Results and Discussion}

Soils were analyzed for mechanical composition, $\mathrm{pH}$, organic matter, total nitrogen, available phosphorus and potassium. (Figures 4-9 and Table 3-6).

\section{Soil texture}

Soil texture is a permanent attribute of soils. Crop production, land use and land management are greatly affected by soil texture and also it has a direct role in water infiltration, drainage and nutrient retention (Brady \& Weil, 2008). From the laboratory soil test, seven different classes of soil texture were identified in the study area. The largest area (57.11\%) was sandy loam and only $2.13 \%$ area was with silt loam which is shown in Figure 4 and Table 3. Sandy loam, loam, sandy clay loam site is good for the cultivation of different kinds of crops however special care should be taken for soil conservation and water management in the slopy areas. 


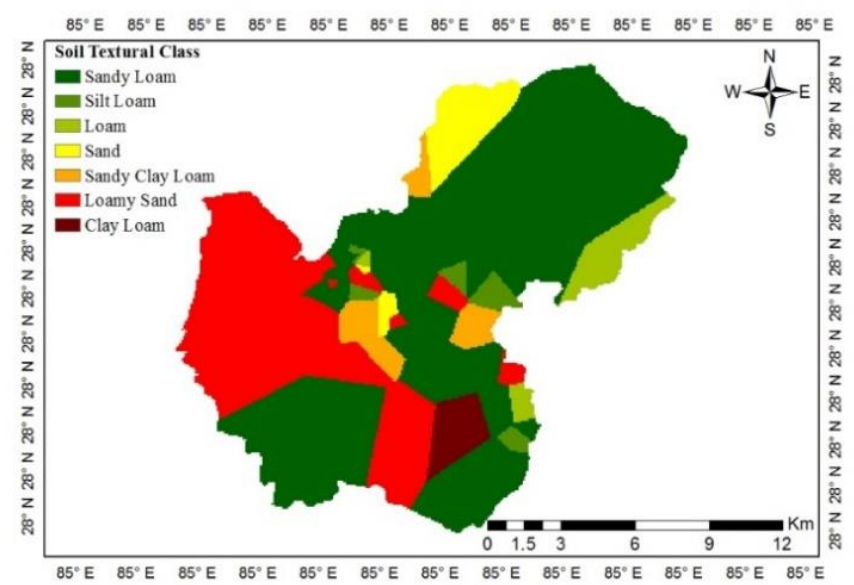

Figure 4. Spatial distribution of soil texture in Rapti Municipality, Chitwan, Nepal

Table 3. Area occupying different soil textural class in the study area

\begin{tabular}{lc}
\hline Textural class & Area (ha) (percentage) \\
\hline Sandy loam & $12134.22(57.11)$ \\
Silt loam & $452.84(2.13)$ \\
Loam & $767.63(3.61)$ \\
Sand & $1005.60(4.73)$ \\
Sandy clay loam & $831.74(3.91)$ \\
Loamy sand & $5505.68(25.91)$ \\
Clay loam & $548.72(2.58)$ \\
\hline Total area & 21246.44 \\
\hline
\end{tabular}

\section{Soil pH}

Soil $\mathrm{pH}$ refers to the acidity and alkalinity of the soil influenced by the presence of different acid and base-forming cations. Soil $\mathrm{pH}$ has an important role in nutrient availability, solubility and plant growth (Brady and Weil, 2008). At higher $\mathrm{pH}$, nutrient such as $\mathrm{Fe}, \mathrm{Cu}$ and $\mathrm{Zn}$, etc are not easily available to the plants and at lower $\mathrm{pH}$, plant nutrient such as $\mathrm{Ca}, \mathrm{Mg}$, Mo and $\mathrm{P}$ remains unavailable (Wang et al., 2006). Alkaline and sodic soils can be reclaimed by using gypsum and sulphuric acid (Amezketa et al., 2005). The application of lime helps to reclaim the acidic soil.

The soil pH in the study area varied from 4.8 to 8.0 with a mean value of 5.96 and a standard deviation of 0.75 . The soil $\mathrm{pH}$ class was distributed from very strongly acidic to moderately alkaline. However, the majority of the area (38.05\%) is under strongly acidic soils followed by moderately acidic (21.76\%) and nearly neutral (19.19\%). About 4.28\% area has slightly alkaline soils as shown in Figure 5 and Table 4. 


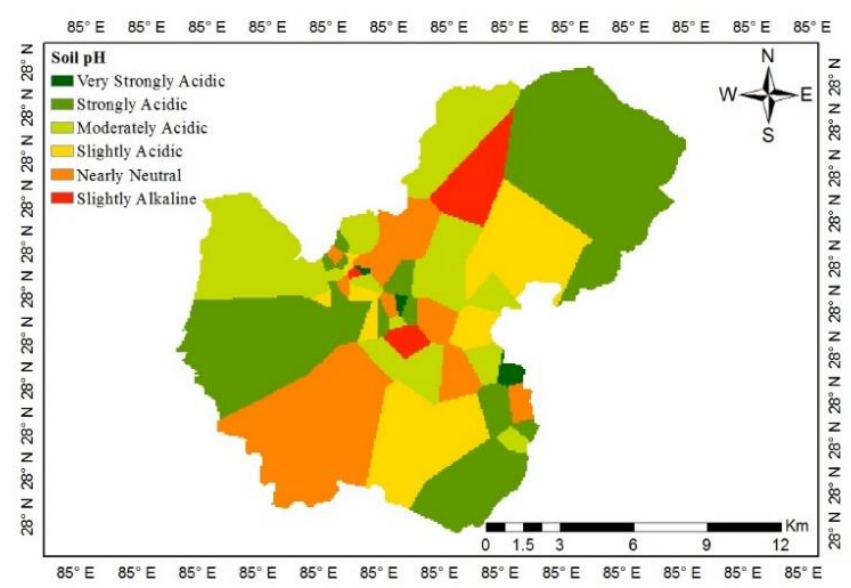

Figure 5. Spatial distribution of soil pH in Rapti Municipality, Chitwan, Nepal

Table 4. Area occupying different pH class in the study area

\begin{tabular}{lc}
\hline pH class & Area (ha) (percentage) \\
\hline Very strongly acidic & $135.16(0.64)$ \\
Strongly acidic & $8084.67(38.05)$ \\
Moderately acidic & $4623.69(21.76)$ \\
Slightly acidic & $3417.08(16.08)$ \\
Nearly neutral & $4077.28(19.19)$ \\
Slightly alkaline & $908.56(4.28)$ \\
\hline Total & $21246.44(100)$ \\
\hline
\end{tabular}

\section{Soil organic matters}

Soil organic matters (SOM) play an important role in the water holding and nutrient storage of soil, stabilizes soil structure, reduces soil erosion, improves drainage and increase the availability of several nutrients such as $\mathrm{Ni}$ trogen, Phosphorous, sulfur and calcium (Ca) (de Bouchervile et. al., 2001). Bouchervile et. al., 2001). SOM improves the soil physical, chemical and biological properties therby maintains the sustainability in cropping system (Fageria, 2012). Organic matters from the different sources can increase the nitrogen mineralizable pool (Sanchez et al., 2001). Soil organic matter (SOM) content in the study area ranges from 1.94 to $3.75 \%$ varying from medium to high with a mean value of $2.73 \%$ as shown in Figure 6. About $76.54 \%$ of the total area has a medium range of SOM content and $23.46 \%$ of the total area has a high range of SOM as shown in Table 6. 


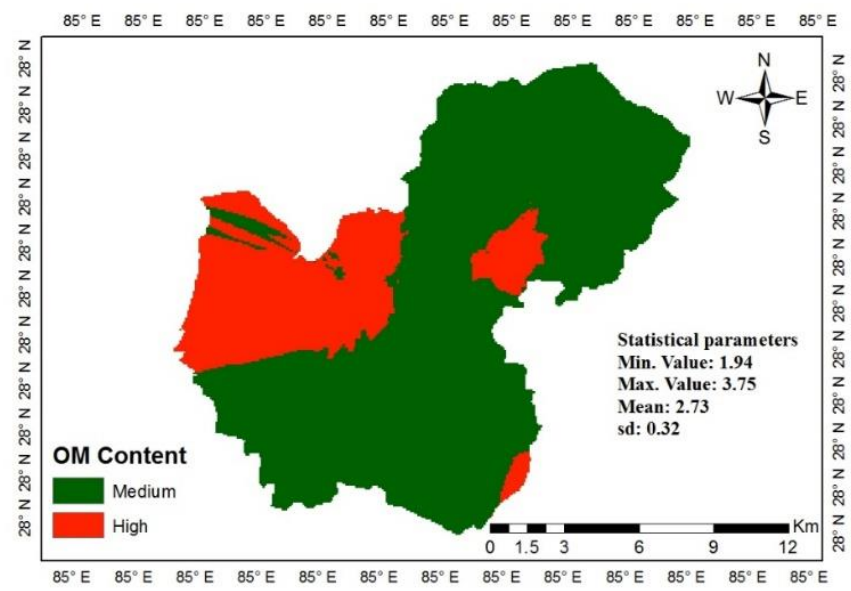

Figure 6. Spatial distribution of soil organic matter in Rapti Municipality, Chitwan, Nepal

\section{Total nitrogen}

Nitrogen is one of the major primary nutrients required for the growth and development of plants. It is an essential constituent of protein, amino acids, chlorophyll which imparts dark green color in plants and promotes vegetative growth (Bloom, 2015). Furthermore, nitrogen also encourages the uptake and utilization of other macronutrients, namely phosphorous and potassium. Deficiency of nitrogen in plants causes retardation of growth, yellowing of leaves, reduce apical dominance and poor vegetative growth of the plants (Bianco et al., 2015). The total nitrogen content in the study area varied from $0.097 \%$ to $0.187 \%$ with the mean value of $0.13 \%$ as shown in Figure 7 and Table 6. Nitrogen content was in the range of medium to high. About $76.54 \%$ of the total area has a medium range of nitrogen in the study area.

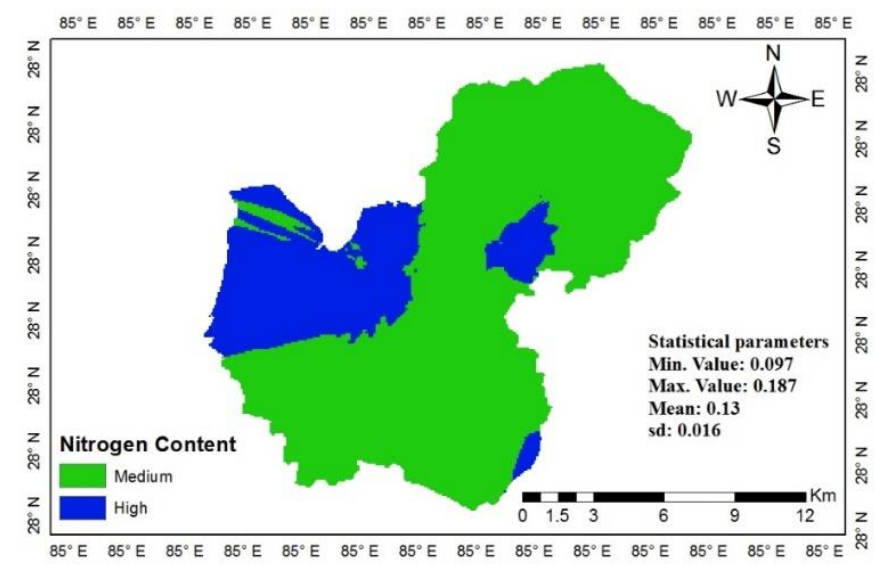

Figure 7. Spatial distribution of total nitrogen in Rapti Municipality, Chitwan, Nepal

\section{Available phosphorous}

Phosphorous is the second most limiting nutrient for the growth and development of plants (Shen et al., 2011). In soils, phosphorous exists in organic and inorganic form and their fate in soil and behavior differs with different forms (Turner et al., 2007). Furthermore, phosphorous increases nodule mass and dry matter yield in legumes (Ssali and Keya, 1983) The available phosphorous content in the study area ranged from 51.03 to $270.10 \mathrm{~kg}$ ha $^{-1}$ with a mean value of $79.13 \mathrm{~kg} \mathrm{ha}^{-1}$ as shown in Figure 8 and Table 6. 


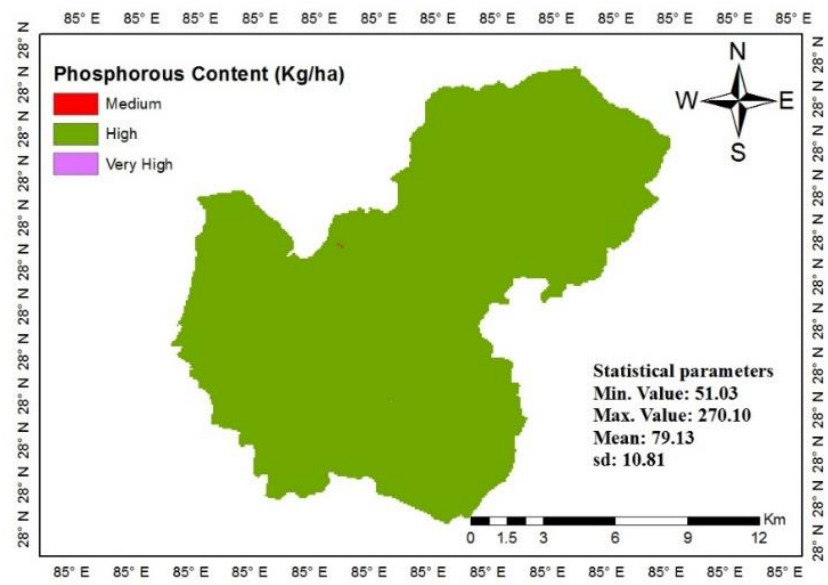

Figure 8. Spatial distribution of available phosphorous in Rapti Municipality, Chitwan, Nepal

\section{Available potassium}

Potassium is the third major plant nutrients after nitrogen and phosphorous which mainly takes part in the activation of enzymes
(Havlin et al., 2010). Available potassium content in the study area ranged from 169.87 to $358.68 \mathrm{~kg} \mathrm{ha}^{-1}$ with a mean value of $267.58 \mathrm{~kg}$ ha $^{-1}$ as shown in Figure 9 and Table 5 and 6.

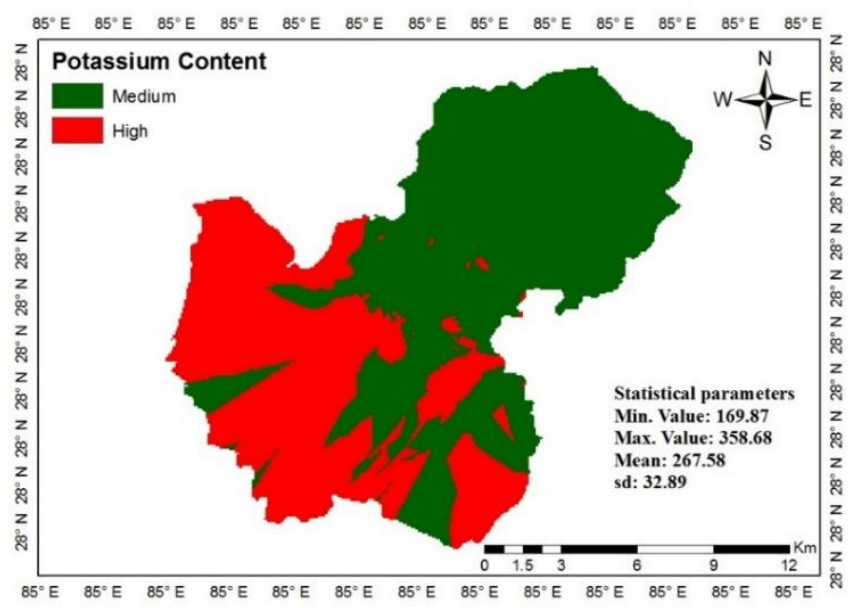

Figure 9. Spatial distribution of available potassium in Rapti Municipality, Chitwan, Nepal

Table 5. Soil fertility status of Rapti Municipality, Chitwan, Nepal

\begin{tabular}{llcccc}
\hline Soil parameters & Unit & Min. value & Max. value & Mean value & $\begin{array}{c}\text { Standard } \\
\text { deviation }\end{array}$ \\
\hline Soil pH & pH scale & 4.8 & 8.0 & 5.96 & 0.75 \\
SOM & $\%$ & 1.94 & 3.75 & 2.73 & 0.32 \\
Total N & $\%$ & 0.097 & 0.187 & 0.13 & 0.016 \\
Available $\mathrm{P}_{2} \mathrm{O}_{5}$ & $\mathrm{~kg} \mathrm{ha}^{-1}$ & 51.03 & 270.10 & 79.13 & 10.81 \\
Available $\mathrm{K}_{2} \mathrm{O}$ & kg ha-1 $^{-1}$ & 169.87 & 358.68 & 267.58 & 32.89 \\
\hline
\end{tabular}

Note: SOM denotes soil organic matter 
B Oli, S Lamichhane, K Oli, 2020 / Use of GIS in soil fertility mapping of Rapti Municipality, Chitwan, Nepal.

Table 6. Area occupying different classes of soil parameters in Rapti Municipality, Chitwan, Nepal

\begin{tabular}{|c|c|c|c|c|}
\hline Soil parameters & SOM & Total nitrogen & $\begin{array}{c}\text { Available } \\
\text { phosphorous }\end{array}$ & $\begin{array}{c}\text { Available } \\
\text { potassium }\end{array}$ \\
\hline Low & - & - & - & - \\
\hline Medium & $\begin{array}{l}16262.33 \\
(76.54 \%)\end{array}$ & $\begin{array}{l}16262.33 \\
(76.54 \%)\end{array}$ & $\begin{array}{r}1.16 \\
(0.005 \%)\end{array}$ & $\begin{array}{l}12715.29 \\
(59.85 \%)\end{array}$ \\
\hline High & $\begin{array}{r}4984.11 \\
(23.46 \%)\end{array}$ & $\begin{array}{r}4984.11 \\
(23.46 \%)\end{array}$ & $\begin{array}{l}21244.71 \\
(99.99 \%)\end{array}$ & $\begin{array}{r}8531.15 \\
(40.15 \%)\end{array}$ \\
\hline Very high & - & - & $\begin{array}{r}0.58 \\
(0.003 \%)\end{array}$ & - \\
\hline Total area (ha) & 21246.44 & 21246.44 & 21246.44 & 21246.44 \\
\hline
\end{tabular}

\section{Conclusion}

The study concluded that the use of GIS, GEP and GPS tools had great importance in soil fertility mapping and its spatial distribution. Based on the soil test data and the use of interpolation tools of GIS, the majority of the Rapti Municipality area had a strongly acidic $\mathrm{pH}$. As suitable soil $\mathrm{pH}$ helps to increase microbial population and nutrient availability to the plants, the area belonging to the strongly acidic to moderately acidic $\mathrm{pH}$ needs quick reclamation either by reduced use of acid-forming fertilizers like urea, ammonium sulfate, etc. or by promoting the use of organic fertilizers like FYM, vermicompost, green manuring, etc. The organic matter level is optimum ranging from medium to high. To maintain their recent status, the use of organic matter with proper management practices should be followed. Primary plant nutrients: nitrogen, phosphorous and potassium level in the soil of the study area were also in the optimum range. However, leaching and runoff of phosphorous in groundwater, canal, ponds and river cause detrimental effects in the environment such as groundwater pollution and eutrophication. This study provides the soil nutrients status of the Rapti Municipality which could help farmers, researchers, government bodies and students. Furthermore, this study would be a basis for sustainable soil management, integrated plant nutrient management, land use planning and site-specific nutrient management to the municipality in near future.

\section{References}

Amezketa, E., Aragüés, R., \& Gazol, R. (2005). Efficiency of sulfuric acid, mined gypsum, and two gypsum byproducts in soil crusting prevention and sodic soil reclamation. Agronomy Journal, 97(3), 983-989. https://doi.org/10.2134/agronj2004.0236

Andújar, D., Rueda-Ayala, V., Jackenkroll, M., Dorado, J., Gerhards, R., \& Fernández-Quintanilla, C. (2013). The nature of sorghum halepense (L.) pers. spatial distribution patterns in tomato cropping fields. Gesunde Pflanzen, 65(3), 85-91.

https://doi.org/10.1007/s10343-013-0301-x

Bermingham, L., Lee, K., \& Lee, I. (2014). Spatio-temporal trajectory region-of-interest mining using Delaunay triangulation. IEEE International Conference on Data Mining Workshop (pp. 1-8).

http://dx.doi.org/10.1109/ICDMW.2014.47

Bianco, M. S., Cecílio Filho, A. B., \& de Carvalho, L. B. (2015). Nutritional status of the cauliflower cultivar 'Verona'grown with omission of out added macronutrients. PloS one, 10(4), Article e0123500. https://doi.org/10.1371/journal.pone.0123500

Binita, N. K., Dasog, G. S., \& Patil, P. L. (2010). Soil fertility mapping in Ghataprabha left bank canal command area of north Karnataka by geographic information system technique. Karnataka Journal of Agricultural Sciences, 22(1).

Bloom, A. J. (2015). The increasing importance of distinguishing among plant nitrogen sources. Current Opinion in Plant Biology, 25, 10-16. https://doi.org/10.1016/i.pbi.2015.03.002

Brady, N. C., \& Weil, R. R. (2008). The nature and properties of soils. Upper Saddle River, NJ: Prentice Hall, 13, 662-710. 
Burrough, P. A., McDonnell, R., McDonnell, R. A., \& Lloyd, C. D. (2015). Principles of geographical information systems. Oxford University Press.

de Boucherville Richter, D., Richter Jr, D. D., \& Markewitz, D. (2001). Understanding soil change: soil sustainability over millennia, centuries, and decades. Cambridge University Press.

Fageria, N. K. (2012). Role of soil organic matter in maintaining sustainability of cropping systems. Communications in Soil Science and Plant Analysis, 43(16), 2063-2113.

https://doi.org/10.1080/00103624.2012.697234

FAO, UNICEF, WFP, \& WHO (2019). The State of Food Security and Nutrition in the World 2019-Safeguarding against economic slowdowns and downturns'. Rome, FAO.

Gunarathna, M. H. J. P., Kumari, M. K. N., \& Nirmanee, K. G. S. (2016). Evaluation of interpolation methods for mapping $\mathrm{pH}$ of groundwater. International Journal of Latest Technology in Engineering, Management \& Applied Science, 3, 1-5.

Havlin, H. L., Beaton, J. D., Tisdale, S. L., \& Nelson, W. L. (2010). Soil Fertility and Fertilizers: An Introduction to Nutrient Management. PHI Learning Private Limited, New Delhi. India.

Huang, B., Sun, W., Zhao, Y., Zhu, J., Yang, R., Zou, Z., Ding, F., Su, J., (2007). Temporal and spatial variability of soil organic matter and total nitrogen in an agricultural ecosystem as affected by farming practices. Geoderma 139(3-4):336-345. https://doi.org/10.1016/i.geoderma.2007.02.012

IFPRI (2017). 2017 Global Food Policy Report. Washington, DC: International Food Policy Research Institute.

Khadka, D., Lamichhane, S., Amgain, R., Joshi, S., Vista, S. P., Sah, K., \& Ghimire, N. H. (2019). Soil fertility assessment and mapping spatial distribution of Agricultural Research Station, Bijayanagar, Jumla, Nepal. Eurasian Journal of Soil Science, 8(3), 237-248

Khadka, D., Lamichhane, S., Bhurer, K. P., Chaudhary, J. N., Ali, M. F., \& Lakhe, L. (2018). Soil Fertility Assessment and Mapping of Regional Agricultural Research Station, Parwanipur, Bara, Nepal. Journal of Nepal Agricultural Research Council, 4, 33-47. https://doi.org/10.3126/jnarc.v4i1.19688

Kumke, T., Schoonderwaldt, A., \& Kienel, U. (2005). Spatial variability of sedimentological properties in a large Siberian lake. Aquatic Sciences, 67(1), 86-96.
Liu, Z.P., Shao, M.A., \& Wang, Y.Q., 2013. Spatial patterns of soil total nitrogen and soil total phosphorus across the entire Loess Plateau region of China. Geoderma 197-198: 67-78.

https://doi.org/10.1016/i.geoderma.2012.12.011

Nepal Demographic and Health Survey 2016. In. Kathmandu, Nepal: Ministry of Health (Nepal), New ERA, and ICF International.

MoAD (2016) Statistical information on Nepalese agriculture 2072/2073 (2015/2016) and series

Panda, S.C., (2010). Soil Management and Organic Farming. Agrobios, Bharat Printing Press, Jodhpur, India.

Patil, P. L., Kuligod, V. B., Gundlur, S. S., Katti, J., Nagaral, I. N., Shikrashetti, P., ... \& Dasog, G. S. (2016). Soil fertility mapping in Dindur sub-watershed of Karnataka for site specific recommendations. Journal of the Indian Society of Soil Science, 64(4), 381-390.

Rawal, N., Acharya, K. K., Bam, C. R., \& Acharya, K. (2018). Soil fertility mapping of different VDCs of Sunsari District, Nepal using GIS. International Journal of Applied Sciences and Biotechnology, 6(2), 142-151. https://doi.org/10.3126/ijasbt.v6i2.20424

Sanchez, J. E., Willson, T. C., Kizilkaya, K., Parker, E., \& Harwood, R. R. (2001). Enhancing the mineralizable nitrogen pool through substrate diversity in long term cropping systems. Soil Science Society of America Journal, 65(5), 1442-1447. https://doi.org/10.2136/sssaj2001.6551442x

Shen, J., Yuan, L., Zhang, J., Li, H., Bai, Z., Chen, X., ... \& Zhang, F. (2011). Phosphorus dynamics: from soil to plant. Plant Physiology, 156(3), 997-1005. https://doi.org/10.1104/pp.111.175232

Ssali, H., \& Keya, S. O. (1983). The effect of phosphorus on nodulation, growth and dinitrogen fixation by beans. Biological Agriculture \& Horticulture, 1(2), 135-144.

https://doi.org/10.1080/01448765.1983.9754387

Turner B. L., Richardson A. E., \& Mullaney E. J. (2007) Inositol Phosphates: Linking Agriculture and the Environment. CAB International, Wallingford, UK.

Wang, J. P., Raman, H., Zhang, G. P., Mendham, N., \& Zhou, M. X. (2006). Aluminium tolerance in barley (Hordeum vulgare L.): physiological mechanisms, genetics and screening methods. Journal of Zhejiang University Science B, 7(10), 769-787. 